\title{
Designing Information Systems for Transaction and Production Data Management A\&N convection
}

\author{
Nadya Rosanna ${ }^{1}$, Hery ${ }^{2}$, Andree E. Widjaja ${ }^{3}$ \\ Fakultas IImu Komputer \\ Universitas Pelita Harapan \\ Tangerang, Indonesia \\ e-mail:nadyarosanna@gmail.com , hery.fik@uph.edu ,andree.widjaja@uph.edu
}

To cite this document:

Rosanna, N., Hery, H., \& Widjaja, A. E. (2020). Designing Information Systems for Transaction and Production Data Management A\&N convection. IAIC Transactions on Sustainable Digital Innovation (ITSDI), 2(2), 120-129.

DOI : https://doi.org/10.34306/itsdi.v2i2.390

\begin{abstract}
Many companies have implemented technology in conducting their business, one of them is by using information systems in managing their business. The business process that runs on the Konveksi A\&N is still manual because the Konveksi A\&N has not implemented or is familiar with information systems like other companies has. This causes all the data collection process of goods, production, and transactions are all documented in different books, making it possible for errors in recording and calculating the data. In addition, the owner also needs to come directly to the location to find out new data or updated data where this takes more time. This research aims to establish a web-based system that can make business processes in Konveksi A\&N more effective. This web-based system will be built using a system development methodology in the form of a prototyping method that uses the Hypertext Preprocessor (PHP) programming language. System modelling was developed using UML 2.5, use case diagrams, activity diagrams, and class diagrams. The final result of this study is a website-shaped information system that can document all data contained in the Konveksi A\&N such as the existence of a master data that contains all the data of convection, production data, and also transaction data to facilitate the owner in checking back all activities that occur in Konveksi A\&N. There are also some reports about the transaction that can display information related to data contained in the system.
\end{abstract}

Keywords: Prototyping, UML, PHP, Konveksi

Designing Information Systems for... 


\section{Introduction}

In running a business, there are many things that need to be managed and considered to be able to run the business properly. One of the most important things is data management. Data is the most important asset in a business. Therefore, companies need to store this data properly. One way to be able to store these data neatly and effectively is by using a system. [1]. Systems are closely related to technology, this is because technology is a means that can support the system to work more effectively and faster [2]. With the development of technology today, individual activities become easier. In addition, companies have also used a lot of technology with a system in the company.

Before discussing the system, there is previous research that discusses the production information system at CV Bintang Selatan. In this research, they created a system to store all existing data in the company into a database. This is done to make it easier for companies to search for data and to provide a back-up system. In addition, there is also a numbering system on forms that were not previously implemented to make it easier to organize and track data. From this study, it is concluded that with this system the company can minimize errors in data storage and make it easier to store and track data and make reports [3].

Currently, A\&N Convection still uses manual processes in managing its business processes. By using paper in taking notes, using chat when ordering, and having to meet face to face when asking employees something new or already done. In terms of making reports, they still use paper, so it is necessary to find back one by one of the data that has occurred within a certain time. This makes the A\&N Convection business flow not yet running effectively and quickly and can result in inaccurate information. Therefore, there is a need for a system that can simplify the A\&N Convection business process flow. This system will be created in the form of a website that can be accessed by owners and employees alike.

\section{Literature Review}

\section{A. Purchasing, Sales, Production, and Information Systems}

Purchasing is an activity carried out to obtain goods and services for a specific purpose [4]. Kotler said that sales are a way for producers to buy products/services offered [4]. Meanwhile, Swastha said selling also includes getting other people to buy goods or services [5]. Production is an activity that aims to create and make a product in the form of goods or services. Production activities require human labour, natural resources, capital in all its forms, and expertise to make things. [6]. Meanwhile, an information system is an amalgamation of people, hardware, software and other components that are useful for managing information in an organization [7].

\section{B. Prototyping, HTML, PHP, and CSS}

A prototype is an early version of a software system used to demonstrate and perform design experiments, [8]. Hypertext Markup Language is a standard programming language used to create a web page [9]. Websites created with HTML can be seen by anyone connected to the internet. Hypertext Preprocessor is a scripting server programming language that functions to create a dynamic web. In principle, the server will work if there is a request from the client [10]. Cascading Style Sheet is used to organize and design a web interface that is integrated into HTML [11]. 
C. Codelgniter $(\mathrm{Cl})$ and Java Script

Codelgniter is a web application framework with PHP programming that applies the Model-View-Controller (MVC) concept [12]. JavaScript is a programming language used to make interactions on web pages. [13]. MySQL functions to process databases using SQL language. [14].

\section{Use Case, Activity and Class Diagram}

Use cases serve to provide an overview of the interactions relating to the system and its environment. The use case model can be described in a use case diagram, [15]. Activity diagrams describe the workflow of business processes in a system [16]. Class diagrams describe a state consisting of attributes, properties and functions in a system [17].

\section{Research Methodology}

The research methodology used consists of two parts, namely the data collection method and the system development method.

\section{A. Method of collecting data}

The methods used in data collection are literature study and interviews. The interview method was conducted to determine the scope of the system and to collect the requirements needed in making the system. Meanwhile, literature studies are conducted to identify and study existing systems by looking at various sources, journals, documentation books, the internet, and libraries. In addition, literature studies are also carried out to help find out the correct flow of making the system.

\section{B. Systems Development Method}

The method used in system development is prototyping. In the prototyping method, researchers and users can interact with each other during the process of making the system in progress, so that the system created can suit user needs without any errors in delivery to researchers.

\section{Results And Discussion}

A. Figure 4.1 is a use case diagram of the proposed system. 


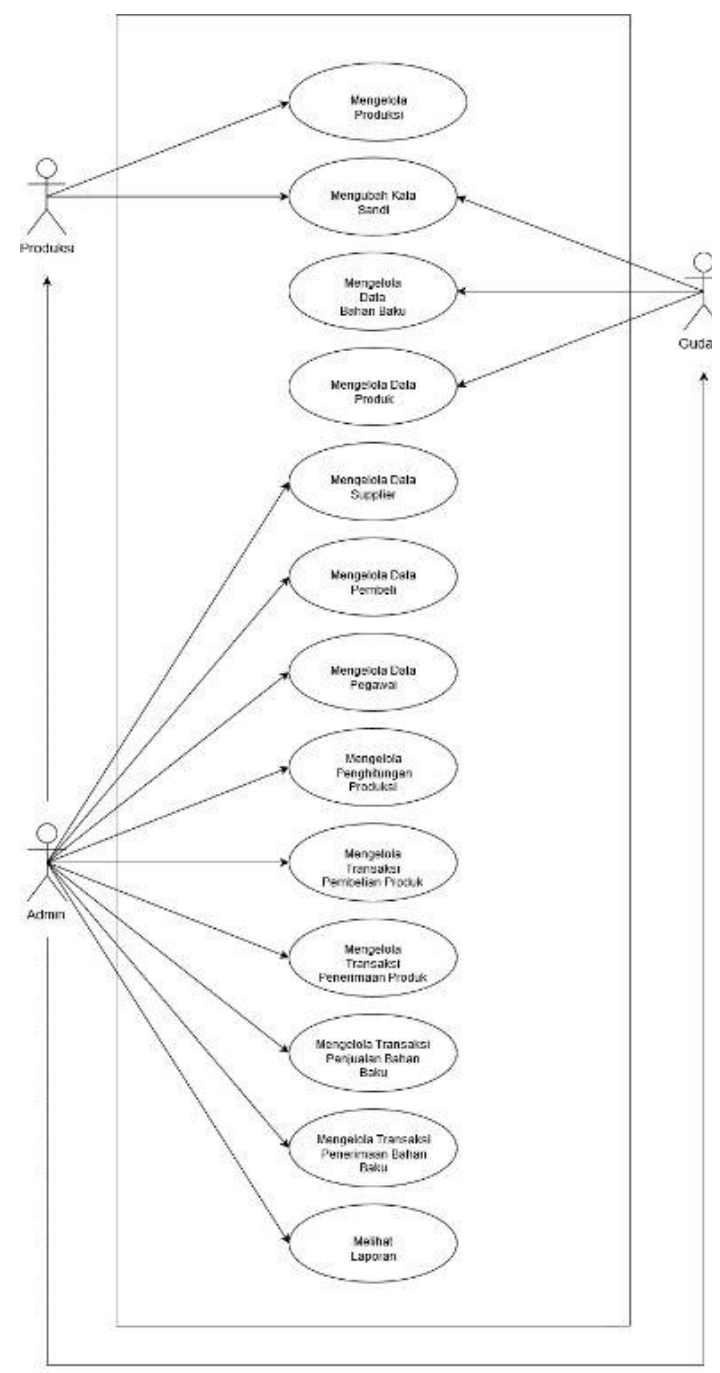

Figure 4.1 Use Case Diagram of the Proposed System

Figure 4.2 is a class diagram of the proposed system. 


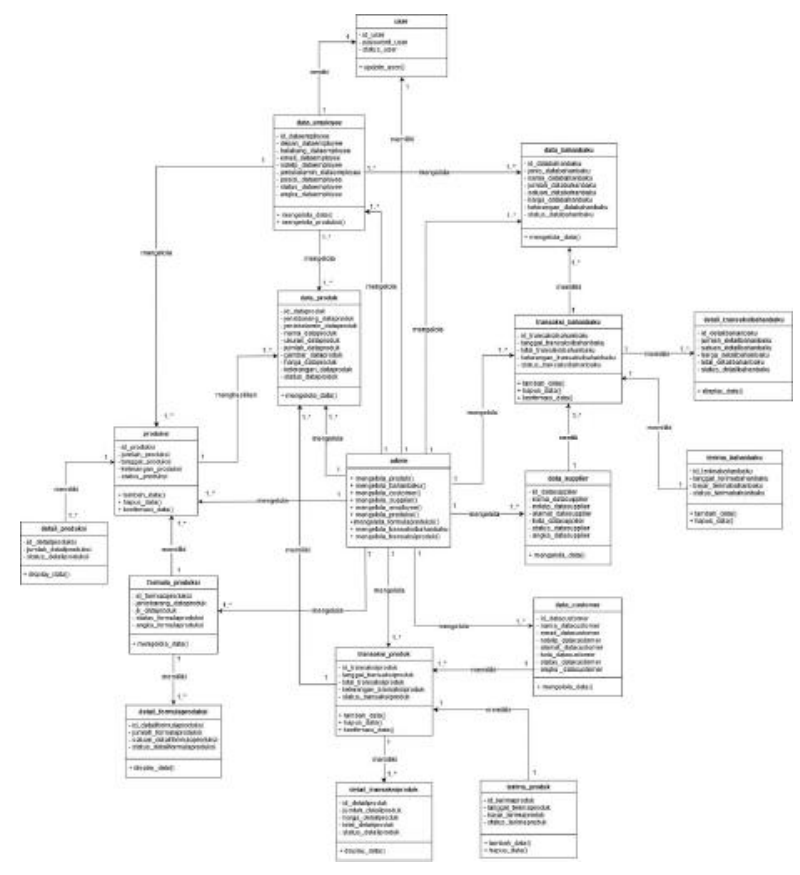

Figure 4.2 Class Diagram of the Proposed System

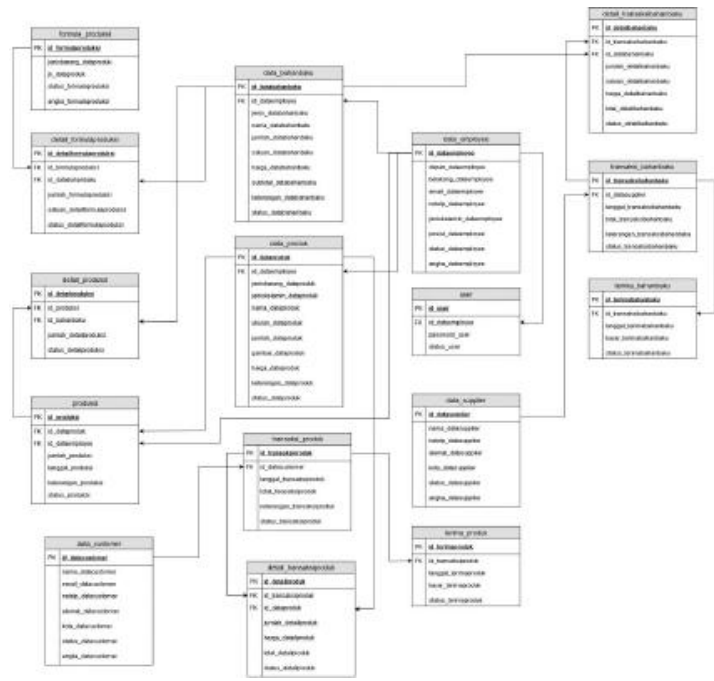

Figure 4.3 Table Relationship Diagram of the Proposed System

The proposal system made in this study aims to display and manage data both goods data production, and transactions contained in A\&N Convection. The following is the interface layer design of the proposed system.

When the user has logged in, the first page that will appear is the dashboard page as shown in Figure 4.4. 


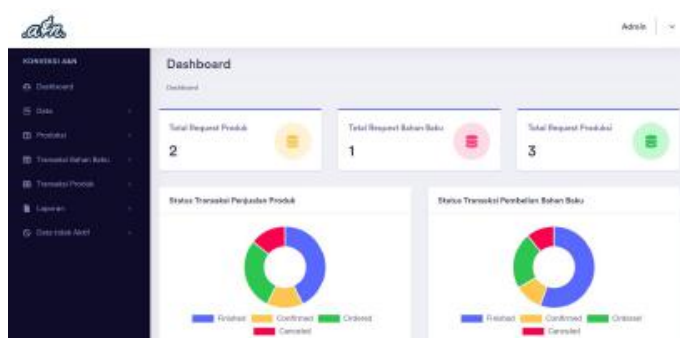

Figure 4.4 Dashboard page

Here is one of the page views managing the data contained in the proposed system. Figure 4.5 is a page for managing product data. This page contains a list of the products contained in the system.

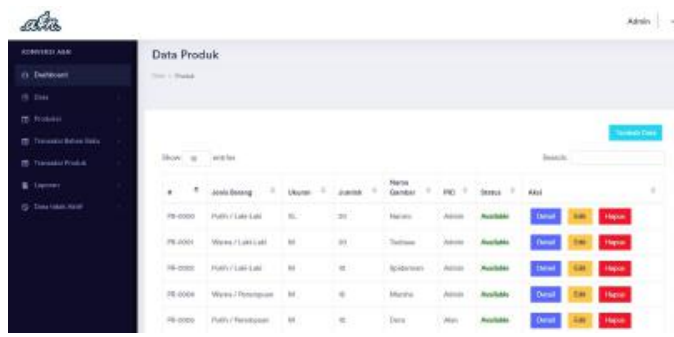

Figure 4.5 Managing Data Page

The following is a display of the data edit page contained in the proposed system. Figure 4.6 is a raw material data editing page. This page contains a form according to the data that has been previously entered.

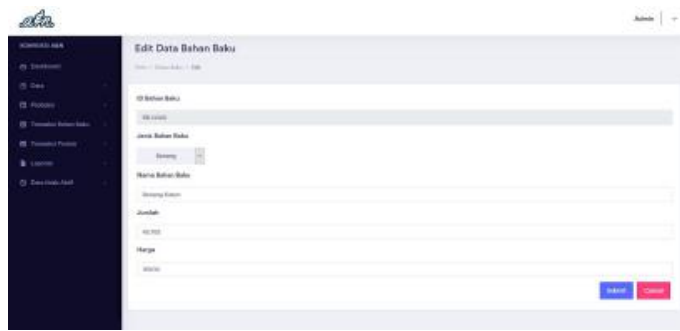

Figure 4.6 Edit Data Page

Figure 4.7 is a page adding production data. On this page, the user can select the product to be produced, then the system will calculate the amount of raw material according to the number of products entered by the user. 


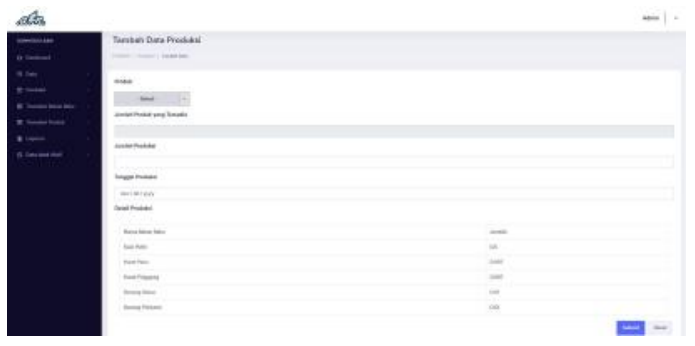

Figure 4.7 Add Production Page

Figure 4.8 and Figure 4.9 is a page to add transaction data. On the add raw material transaction page, users can enter supplier data and any raw materials purchased by entering the amount and price when placing an order. On the add product transaction page, users can enter buyer data and what products are purchased by entering the amount and price according to the existing provisions.

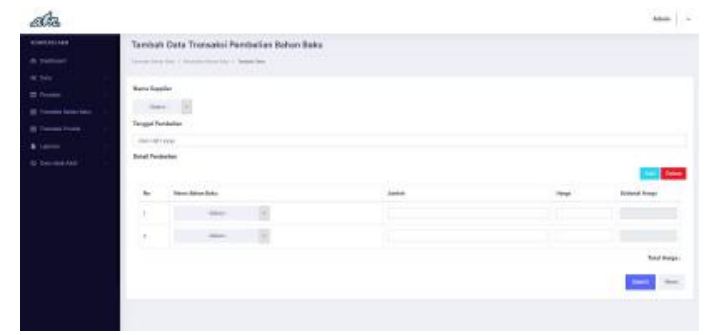

Figure 4.8 Add Raw Material Transaction page

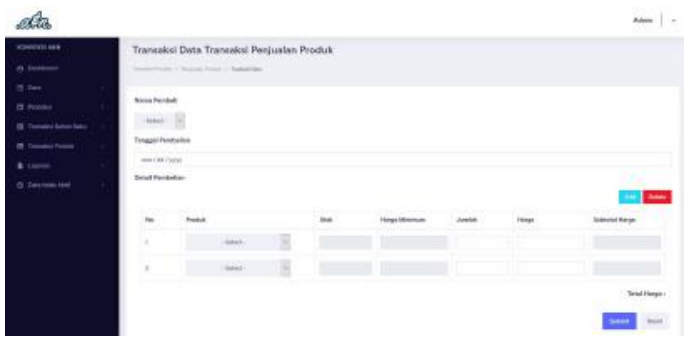

Figure 4.9 Add Product Transaction page

The following is one of the inactive data page views contained in the proposed system. Figure 4.10 is an inactive buyer data page. This page contains a list of buyer data that has been deleted. If the data is still needed, the user can perform a restore to restore the data to the data management page, but if the data is no longer needed, the user can delete the data on the inactive data page to delete data from the system.

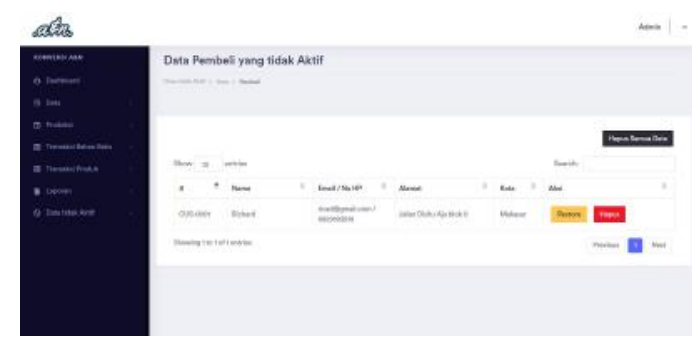

Figure 4.10 Data Off-page 
The following is an example table from the testing process of this proposed system.

\begin{tabular}{|c|c|c|c|}
\hline \multicolumn{4}{|c|}{$\begin{array}{l}\text { Test Number: } 1 \\
\text { Test Subject: Pemilik Konvelksi A\&N }\end{array}$} \\
\hline \multicolumn{4}{|c|}{ Fungsi: Memperbahanui Data Penghitungan Preduksi } \\
\hline Kondisi_Awal & Event & Expected Result & $\begin{array}{l}\text { Result } \\
(\mathrm{P} / \mathrm{F})\end{array}$ \\
\hline $\begin{array}{l}\text { 1) Pengguna telah } \\
\text { melakukan login. } \\
\text { 2) Pengguna } \\
\text { mengakses menu } \\
\text { "Penghitungan } \\
\text { Preduksi". }\end{array}$ & $\begin{array}{l}\text { Memilihg menu "Edif" } \\
\text { pada halaman } \\
\text { "Penghitungan } \\
\text { Produksi". }\end{array}$ & $\begin{array}{l}\text { Sistem akan } \\
\text { menampilkan formulit } \\
\text { edit data penghitungan } \\
\text { produksi. }\end{array}$ & $\mathrm{P}$ \\
\hline $\begin{array}{l}\text { Pengguna mengisi } \\
\text { selunuh data yang } \\
\text { dibutublang dengan } \\
\text { benar. }\end{array}$ & $\begin{array}{l}\text { Memilih menu } \\
\text { "Submif". }\end{array}$ & $\begin{array}{l}\text { Sistem akan } \\
\text { memperbaharui data yang } \\
\text { sudah, dissi ke dalam } \\
\text { sistem dan menampilkan } \\
\text { halaman daftar } \\
\text { penghitungan produksai. }\end{array}$ & $\mathrm{P}$ \\
\hline $\begin{array}{l}\text { 1) Pengguna } \\
\text { mengalsses,menu } \\
\text { "Data tidak Alttif". } \\
\text { 2) Pengguna } \\
\text { mengabses menu } \\
\text { "Penghitungan } \\
\text { Produksi". }\end{array}$ & $\begin{array}{l}\text { Memilih menu } \\
\text { "Restore" pada } \\
\text { halaman } \\
\text { "Penghitungan } \\
\text { Produlssi". }\end{array}$ & $\begin{array}{l}\text { Sistem akan } \\
\text { mengembalikan data } \\
\text { yang tidak altiff.ke dalam } \\
\text { daftar data yang altifdan } \\
\text { akan menampilkan } \\
\text { halaman daftar } \\
\text { penghitungan produksi. }\end{array}$ & $\mathrm{P}$ \\
\hline
\end{tabular}

Figure 4. 11 Example of a Test Case Table

\section{Conclusions And Suggestions}

\section{A. Conclusions}

The completion of this research has resulted in a website that is used to assist the process of data management, recording transactions and production and reporting on A\&N Convection. With this system, it is hoped that users will find it easier to obtain the necessary data and be more effective in collecting data without the need for repetition. This website has been designed in accordance with the requests and needs of the A\&N Convection obtained from the results of surveys and interviews conducted so that the system can be used to help and meet the needs of A\&N Convection.

This website has fulfilled user needs such as: providing a forum for A\&N Convection to store and document existing data, making it easier for users to manage data on goods, production, and buying and selling transactions; make it easier for users to know the needs of goods and products with the information in the system, make it easier for users to find existing data more effectively and quickly, facilitate the provision of reports on production activities and ongoing transactions.

\section{B. Suggestion}

The suggestions that can be proposed for making the next system are to develop the existing system in A\&N Convection that can be integrated with other systems, for example, a transaction system carried out online, adding other types of reports such as financial reports to be able to find out how much profit is made, etc. to improve convection performance, further develop the system in the form of mobile applications to make it easier for users to access the system. 


\section{References}

[1] T. Sutabri, Pengantar Teknologi Informasi., Yogyakarta: Andi, 2014.

[2] Rusman, Pembelajaran Berbasis Teknologi Informasi dan Komunikasi, Jakarta: Rajawali Pers, 2013.

[3] A.P. Gunawan, A. L. Maukar, D. E. S. Rahaju, "Perancangan Sistem Informasi Produksi di CV. Bintang Selatan," Vols. Vol. 9, No. 2., 2010.

[4] P. Kotler, Manajemen Pemasaran, Jakarta: Perhalindo, 2007.

[5] B. Swastha, Manajemen Penjualan, Yogyakarta: BPFE, 2008.

[6] S. Sukirno, Pengantar Teori Mikroekonomi, Jakarta: Raja Grafindo, 2002.

[7] R. McLeod, Sistem Informasi Manajemen, Jakarta: PT. Prenhallind, 2004.

[8] Sommerville, Software Engineering Ninth Edition, Massachusetts: Addison- Wesley, 2011.

[9] A. F. K. Sibero, Kitab Suci Web Programing, Jakarta: Mediakom, 2012.

[10] D. R. A. Yeni Kustiyahningsih, Pemrograman Basis Data Berbasis WEB Menggunakan PHP dan Mysql, Yogyakarta: Graha IImu, 2011.

[11] B. Kurniawan, Desain Web Praktis dengan CSS, Jakarta: Elexmedia Komputindo, 2008.

[12] A. Griffiths, Codelgniter 1.7 Professional Development, Birmingham: Packt Publishing, 2010.

[13] D. R. Anamisa, Pemograman Basis Data Berbasis Web Menggunakan PHP \& MySQL, Yogyakarta: Graha IImu, 2011.

[14] N. Bunafit, PHP dan MySQL dengan Editor Dreamweaver MX, Yogyakarta: ANDI, 2004.

[15] P. P. Widodo, Menggunakan UML, Bandung: Informatika, 2011.

[16] A. Hendini, "Pemodelan UML Sistem Informasi Monitoring Penjualan dan Stok Barang," Jurnal Khatulistiwa Informatika, Vol. IV, No. 2, 2016.

[17] Basuki, "Sistem Informasi Nilai Mata Pelajaran Dengan Metodologi Berbasis Objek," Jurnal Sisfotek Global, Vol. 7 No. 1, 2017.

[18] M. S. Rosa, "Rekayasa Perangkat Lunak Berstruktur dan Berorientasi Objek," Informatika, 2013.

[19] B. H. Wixom. \&. R. A. Dennis, Systems Analysis and Design: An Object-Oriented Approach with UML, Fifth Edit, New York: John Wiley \& Sons, Inc, 2015.

[20] Febriyanto, E., Naufal, R. S., \& budiarty, frizca. (2019). Attitude Competency Assessment in the 2013 curriculum based on elementary school Prototyping methods. IAIC Transactions on Sustainable Digital Innovation (ITSDI), 1(1), 87-96. https://doi.org/10.34306/itsdi.v1i1.6 
[21] Sunarya, P. A., Aini, Q., Bein, A. S., \& Nursaputri, P. (2019). The Implementation Of Viewboard Of The Head Of Department As A Media For Student Information Is Worth Doing Final Research. ITSDI Journal Edition Vol. 1 No. 1 October 2019, 18.

[22] Febriyanto, E., \& Naufal, R. S. (2019). Attitude Competency Assessment in the 2013 Curriculum Based On Elementary School Prototyping Methods. IAIC Transactions on Sustainable Digital Innovation, 1(1), 87-96.

[23] Yusup, M., Aini, Q., Apriani, D., \& Nursaputri, P. (2019, December). PEMANFAATAN TEKNOLOGI BLOCKCHAIN PADA PROGRAM SERTIFIKASI DOSEN. In SENSITIf: Seminar Nasional Sistem Informasi dan Teknologi Informasi (pp. 365-371)

[24] Rao, S. S., \& Siddaiah, P. (2020). Design of Eight-Phase Sequences using Modified Particle Swarm Optimization for Spread Spectrum and Radar Applications. APTIKOM Journal on Computer Science and Information Technologies, 6(1), 30-40. https://doi.org/10.34306/csit.v6i1.368

[25] S, S., T, R., \& SP, S. (2020). An optimized Rubber Sheet Model for Normalization Phase of IRIS Recognition . APTIKOM Journal on Computer Science and Information Technologies, 6(1), 20-29. https://doi.org/10.34306/csit.v6i1.356 